\title{
Profil Hormon Progesteron dan Gen Fekunditas terhadap Sifat Kembar Kambing PE Betina Calon Induk
}

\author{
The Profile of Progesterone Hormone and Fecundity Genes to the Twin Characteristics of Etawah- \\ grade Does \\ R. H. Mulyono'), C. Sumantri' ${ }^{2)}$, R. R. Noor ${ }^{2)}$, Jakaria' ${ }^{2)}$, D. A. Astuti ${ }^{\text {) }}$ \\ 1) Mahasiswa Program Studi Ilmu Produksi dan Teknologi Peternakan, Sekolah Pascasarjana, ,Institut \\ Pertanian Bogor, \\ 2) Departemen Ilmu Produksi dan Teknologi Peternakan, Fakultas Peternakan, Institut Pertanian Bogor \\ 3) Departemen Ilmu Nutrisi dan Teknologi Pakan, Fakultas Peternakan, Institut Pertanian Bogor, \\ Jl.Agatis, Kampus IPB Dramaga, Bogor 16680, Indonesia \\ Email koresponden author: rini.herlina@gmail.com
}

\begin{abstract}
Etawah-grade goat is a graded up line between kacang and etawah goats, which well adapted to Indonesia's humid tropical climate. The good reproductive trait of Etawah-grade does are inherited from kacang goat (prolific goat). This study used six heads of Etawah-grade does at 1-2 years old ( $I_{1}$ dental condition). IPB University. The body variables were withers height, hip height, body length, chest width, chest depth, thurl width, rump length, chest girth, and cannon circumference, whereas for head variables were acrocranion-prosthion, basion-prosthion, lower jaw length, head height, tuber facial left-right, nasion-rhinion, entorbitale left-right, euryon left-right, supraorbitale left-right. Body score and head score were obtained from Principal Component Analysis (PCA). PCR-RFLP technique was used to determine genotypes of fecundity genes BMP15 (exon 1), BMPR1B (exon 1), KISS1 (exon 1) and KISS1 (intron 1) with restriction enzymes AluI (AG|CT), SduI (GDGCH|C), BsrI (ACTGG|) and MwoI (GCCTAAG|TAGC), respectively. Progesterone leves were measured by EIA (enzyme immuno assay). The results showed that the association between crude fat consumption and progesterone profile was found in this study, but it was not related to twin births with certain genotypes of gene fecundity BMP15 (exon 1), BMPR1B (exon 1), KISS1 (exon 1) and KISS1 (intron 1). The progesterone profile during the pregnancy period did not correlate to their body size and head size.
\end{abstract}

Keywords: body score, Etawah-grade does, fecundity genes, head score, progesterone profile.

\section{PENDAHULUAN}

Kambing peranakan etawah lebih dikenal dengan sebutan kambing PE. Menurut Atabany et al. (2001) kambing PE merupakan kambing hasil grading up antara kambing kacang dan kambing etawah. Batubara et al. (2006) menyatakan bahwa kambing kacang merupakan kambing asli Indonesia penghasil daging dan kulit dan bersifat prolifik, sedangkan Rout dan Dass (2015) menyatakan bahwa kambing etawah merupakan kambing dwiguna penghasil daging dan susu, yang berasal dari daerah Chakkar Nagar di Distrik Etawah, Uttar Pradesh. Kambing etawah diimpor dari India pada masa kolonialisasi Belanda di Indonesia (Sutama 2009). Menurut Kostaman dan Sutama (2006) kambing PE merupakan kambing dwiguna penghasil susu dan daging.

Kambing PE menyebar di berbagai wilayah pelosok tanah air karena kemampuan adaptasi yang baik pada lingkungan tropis lembab Indonesia. Sifat reproduksi baik pada kambing PE diwarisi dari kambing kacang yang bersifat prolifik. Salah satu hormon reproduksi yang bertanggung jawab terhadap sifat prolifik adalah progesteron. Hormon progesteron dihasilkan oleh corpus luteum (badan kuning) dalam folikel ovarium, berfungsi mempersiapkan uterus untuk kelangsungan kebuntingan secara normal (Temple 1993). Sutama et al. (2012) menjelaskan bahwa progesteron yang terutama dihasilkan oleh corpus luteum berfungsi untuk mempertahankan kebuntingan dan untuk perkembangan ambing dan produksi susu.

Diagnosis kebuntingan pada kambing dengan metode EIA (enzyme immuno assay) telah dilakukan oleh Boscos et al. (2003), yang juga digunakan pada penelitian ini. Hasil penelitian Boscos et al. (2003) menyatakan bahwa kebuntingan dapat dideteksi pada 21 hari setelah inseminasi buatan, pada konsenterasi progesteron sebesar 1,5 dan 2,5 ng $\mathrm{mL}^{-1}$. Sutama et al. (2012) melaporkan bahwa konsentrasi progesteron pada minggu kedua (hari ke10-14) setelah kawin bervariasi antara individu yaitu antara 2,7-12,5 ng mL ${ }^{-1}$. Dijelaskan lebih lanjut bahwa konsentrasi hormon progesteron ini relatif tetap pada bulan pertama 
masa kebuntingan. Thornburn dan Schneider (1972) melaporkan bahwa konsentrasi progesteron plasma selama kehamilan awal $\left(2,5-3,5 \mathrm{ng} \mathrm{mL}^{-1}\right)$ serupa dengan nilai fase luteal dan tetap stabil dari hari ke-8 sampai hari ke-60, sedangkan antara hari ke-60 dan 70 peningkatan konsentrasi progesteron sekunder terjadi dan dipertahankan pada 4,5-5,5 ng $\mathrm{mL}^{-1}$ sampai sebelum parturasi. Peningkatan konsentrasi progesteron sekunder pada kambing dengan anak kembar lebih besar. Penurunan konsentrasi progesteron dengan cepat terjadi selama 1-2 hari sebelum kelahiran, tetapi konsentrasinya ditemukan masih cukup tinggi pada hari kelahiran yaitu 1,25 ng mL-1. Menurut Boscos et al. (2003) kebuntingan dapat dideteksi pada 21 hari setelah inseminasi buatan pada kambing, yaitu pada konsentrasi progesteron sebesar 1,5 dan 2,5 ng mL-1. Sardjana (1994) melaporkan bahwa kambing yang memiliki konsentrasi progesteron lebih besar dari $3 \mathrm{ng} \mathrm{mL}^{-1}$ dapat saja tidak menghasilkan anak karena terjadi resorpsi embrio atau keguguran yang tidak diketahui atau faktor penyakit yang menjadi penyebab dari gangguan kebuntingan. Tujuan penelitian ini adalah untuk menggambarkan hubungan antara profil progesteron darah selama kebuntingan dengan status kelahiran anak pada kambing PE betina calon induk umur 1-2 tahun (kondisi gigi $\mathrm{I}_{1}$ ), dengan ukuran morfometrik tubuh dan kepala serta genotipe dari gen fekunditas BMP15 (exon 1), gen BMPR1B (exon 1), gen KISS1 (exon 1) dan gen KISS 1 (intron 1). Efek konsumsi lemak kasar pada pakan juga diamati pada penelitian ini untuk dihubungkan dengan kelahiran anak kembar.

\section{MATERI DAN METODE}

\section{Lokasi dan Waktu}

Penelitian ini dilaksanakan di di Laboratorium Genetika Molekuler Ternak, Departemen Ilmu Produksi dan Teknologi Peternakan untuk pengamatan gen BMP15 (exon 1), gen BMPRIB (exon 1), gen KISS1 (exon 1) dan gen KISS1 (intron 1) dan di laboratorium lapang Divisi Nutrisi Ternak Daging dan Kerja, Departemen Ilmu Nutrisi dan Teknologi Pakan, Fakultas Peternakan IPB Bogor untuk pengamatan pengukuran permukaan tubuh dan kepala linear kambing betina induk. Penelitian juga dilakukan di Laboratorium Hormon, Divisi Reproduksi dan Rehabilitasi, Departemen Klinik, Reproduksi dan Patologi, Fakultas Kedokteran Hewan IPB untuk pengamatan konsentrasi progesteron darah kambing betina induk.

Pengamatan dilakukan pada Nopember 2015 sampai Oktober 2016, yang meliputi tahapan perkawinan, tahapan pengukuran permukaan tubuh dan kepala linear, tahapan pengambilan sampel darah untuk penentuan genotipe gen $B M P 15$ (exon 1), gen $B M P R 1 B$ (exon 1), gen KISS1 (exon 1) dan gen KISS1 (intron 1) dan pengukuran konsentrasi progesteron darah kambing betina induk.

\section{Materi}

\section{Ternak}

Enam ekor kambing PE betina calon induk pada kondisi gigi $\mathrm{I}_{1}$ (umur 1-2 tahun). Ternak sudah dikawinkan 1 bulan sebelum penelitian dilakukan.

Konsumsi Bahan Kering, Protein Kasar dan Lemak

\section{Kasar}

Konsumsi bahan kering, protein kasar dan lemak kasar yang diberikan pada kambing PE betina calon induk disediakan oleh Laboratorium Analisis Nutrisi Ternak Daging dan Kerja, Departemen Ilmu Nutrisi dan Teknologi Pakan, Fakultas Peternakan IPB. Konsumsi bahan kering, protein kasar dan lemak kasar dalam satuan g ekor ${ }^{-1}$ hari ${ }^{-1}$.

\section{Alat dan Bahan}

Perangkat alat untuk penentuan morfometrik tubuh dan kepala yang meliputi tongkat ukur, kaliper dan pita ukur. Perangkat alat untuk penentuan penentuan gen BMP15 (exon 1), gen BMPR1B (exon 1), gen KISS1 (exon 1) dan gen KISS 1 (intron 1) beserta genotipenya, diuraikan berikut ini. Tabung vacutainer yang berisi EDTA, digunakan untuk menampung darah melalui alat suntik berukuran 5 $\mathrm{mL}$. Tabung ependorf $1,5 \mathrm{~mL}$, alat pengocok (vortex), alat inkubasi, alat pemutar (tilting), alat sentrifius berkecepatan $12000 \mathrm{rpm}$, dan freezer digunakan untuk ekstraksi DNA. Mesin PCR thermocycler untuk mengamplifikasi DNA dengan bahan campuran untuk amplifikasi. Hasil amplifikasi DNA (amplikon) divisualisasikan melalui elektroforesis dalam gel agarose 1,5\%. UV-Transilluminator digunakan untuk visualisasi pita DNA.

Primer

forward

5'-GTGGAGCCTGGATGCTGTTA-3' (dirancang berdasarkan Primer 3 Input version 0.4.0) dan primer reverse 5'-CGGCTTCCT CTGCTGCTTG-3' (Chu et al. 2007), menghasilkan amplikon sebesar $279 \mathrm{pb}$, mengamplifikasi gen BMP15 (exon 1). Amplikon tersebut dapat dipotong dengan enzim restriksi AluI (AG|CT). Primer forward 5'-TGTCTACCATCGTTTCTTCCACT-3' dan primer reverse 5'-GGACAATGGTGGTGGCATTTAC-3' (dirancang berdasarkan Primer 3 Input version 0.4.0), menghasilkan amplikon sebesar $784 \mathrm{pb}$, mengamplifikasi gen $B M P R 1 B$ (exon 1). Amplikon tersebut dapat dipotong dengan enzim restriksi $S d u \mathrm{I}(\mathrm{GDGCH} \mid \mathrm{C})$ yang dalam hal ini adalah GGGCC|C dan GGGCA|C. Primer forward 5'-TGCAAAGCCGAGTGTGCAGG-3' dan primer reverse 5'-TGAAGGCGGTGGCACAAAGGAA-3' (An et al. 2013), menghasilkan amplikon sebesar 594 pb, mengamplifikasi gen KISS1 (exon 1). Amplikon ini dapat dipotong dengan enzim restriksi BsrI (ACTGG|). Primer forward 5'-CCCGCTGTAACTAGAGAAAG-3' dan primer reverse 5'- CATCCAGGGTGAGTGATACT-3' (An et al. 2013), menghasilkan amplikon sebesar 377pb, mengamplifikasi gen KISS1 (intron 1). Amplikon ini dapat dipotong dengan enzim restriksi MwoI (GCCTAAG|TAGC).

Perangkat alat untuk penentuan konsentrasi progesteron darah yang meliputi alat suntik berukuran $5 \mathrm{~mL}$ dan tabung vacutainer plain (tanpa EDTA) untuk mengambil sampel darah; alat sentrifius untuk memanen serum dan freezer untuk menyimpan darah. EIA dengan perlengkapannya dan ultrasonografi (USG) dimensi dua dengan perlengkapannya untuk mendeteksi kebuntingan.

\section{Metode Penelitian}

Pengukuran Permukaan Tubuh Linear Kambing Betina Calon Induk

Variabel permukaan tubuh linear yang diamati meliputi tinggi pundak $\left(\mathrm{X}_{1 \mathrm{t}}\right)$, tinggi pinggul $\left(\mathrm{X}_{2 \mathrm{t}}\right)$, panjang 
badan $\left(\mathrm{X}_{3 \mathrm{t}}\right)$, lebar dada $\left(\mathrm{X}_{4 \mathrm{t}}\right)$, dalam dada $\left(\mathrm{X}_{5 \mathrm{t}}\right)$, lebar pinggul $\left(\mathrm{X}_{6 \mathrm{t}}\right)$, panjang kelangkang $\left(\mathrm{X}_{7 \mathrm{t}}\right)$, lingkar dada $\left(\mathrm{X}_{8 \mathrm{t}}\right)$, lingkar kanon $\left(\mathrm{X}_{9 \mathrm{t}}\right)$ dengan menggunakan tongkat dan pita ukur. Variabel-variabel diukur berdasar-kan Amano et al. (1981) dengan metode pengukuran seperti yang disajikan pada uraian berikut ini.

1. Tinggi pundak $\left(\mathrm{X}_{1 \mathrm{t}}\right)$ diukur dari jarak tertinggi pundak sampai permukaan tanah, menggunakan tongkat ukur.

2. Tinggi pinggul $\left(\mathrm{X}_{2 \mathrm{t}}\right)$ diukur dari jarak tertinggi pinggul sampai permukaan tanah, menggunakan tongkat ukur.

3. Panjang badan $\left(\mathrm{X}_{3 \mathrm{t}}\right)$ diukur dari jarak garis lurus tepi tulang processus spinosus sampai os ischium, menggunakan tongkat ukur.

4. Lebar dada $\left(\mathrm{X}_{4 \mathrm{t}}\right)$ diukur dari jarak antara penonjolan sendi bahu (os scapula) kanan dan kiri, menggunakan kaliper.

5. Dalam dada $\left(\mathrm{X}_{5 \mathrm{f}}\right)$ diukur dari jarak antara titik tertinggi pundak dan tulang dada, menggunakan tongkat ukur.

6. Lebar pinggul $\left(\mathrm{X}_{6 \mathrm{t}}\right)$ diukur dari jarak antara sendi pinggul kanan dan kiri, menggunakan tongkat ukur.

7. Panjang kelangkang $\left(\mathrm{X}_{7 \mathrm{t}}\right)$ diukur dari jarak antara muka pangkal paha sampai ke benjolan tulang tapis, menggunakan tongkat ukur.

8. Lingkar dada $\left(\mathrm{X}_{8 \mathrm{t}}\right)$ diukur melingkar tepat di belakang scapula, menggunakan pita ukur.

9. Lingkar kanon $\left(\mathrm{X}_{9 \mathrm{f}}\right)$ diukur melingkar di tengahtengah tulang pipa kaki depan sebelah kiri, menggunakan pita ukur.

\section{Pengukuran Permukaan Kepala Linear Kambing \\ Betina Calon Induk}

Variabel permukaan kepala linear yang diukur meliputi: akrokranion-prosthion $\left(\mathrm{X}_{1 \mathrm{k}}\right)$, pengukuran basion-prosthion $\left(\mathrm{X}_{2 \mathrm{k}}\right)$, pengukuran panjang rahang bawah $\left(\mathrm{X}_{3 \mathrm{k}}\right)$, pengukuran tinggi kepala $\left(\mathrm{X}_{4 \mathrm{k}}\right)$, pengukuran tuber facial kiri-kanan $\left(\mathrm{X}_{5 \mathrm{k}}\right)$, pengukuran nasion-rhinion $\left(\mathrm{X}_{6 \mathrm{k}}\right)$, pengukuran entorbitale kiri-kanan $\left(\mathrm{X}_{7 \mathrm{k}}\right)$, pengukuran euryon kiri-kanan $\left(\mathrm{X}_{8 \mathrm{k}}\right)$, pengukuran supraorbitale kirikanan $\left(\mathrm{X}_{9 \mathrm{k}}\right)$ dalam satuan $\mathrm{cm}$ dengan menggunakan jangka sorong. Metode pengukuran disajikan pada uraian berikut ini, berdasarkan metode Hayashi et al. (1980) dengan dimodifikasi.

1. Akrokranion-prosthion $\left(\mathrm{X}_{1 \mathrm{k}}\right)$ diukur dari ujung tulang tengkorak sampai batas titik tepi bawah rahang atas.

2. Basion-prosthion $\left(\mathrm{X}_{2 \mathrm{k}}\right)$ diukur dari batas pangkal tulang baji sampai titik tepi bawah rahang atas.

3. Panjang rahang bawah $\left(\mathrm{X}_{3 \mathrm{k}}\right)$ diukur dari ujung titik tepi bawah rahang atas sampai pangkal rahang bawah.

4. Tinggi kepala $\left(\mathrm{X}_{4 \mathrm{k}}\right)$ diukur dari ujung tulang tengkorak sampai rahang bawah.

5. Tuber facial kiri-kanan $\left(\mathrm{X}_{5 \mathrm{k}}\right)$ diukur dari ujung tulang pipi kiri sampai pipi kanan.

6. Nasion-rhinion $\left(\mathrm{X}_{6 \mathrm{k}}\right)$ diukur dari pangkal hidung sampai tulang hidung bagian bawah.

7. Entorbitale kiri-kanan $\left(\mathrm{X}_{7 \mathrm{k}}\right)$ diukur dari pangkal entorbitale (lekuk mata) kiri sampai pangkal entorbitale kanan.

8. Euryon kiri-kanan $\left(\mathrm{X}_{8 \mathrm{k}}\right)$ atau lebar kepala diukur dari pelipis sebelah kiri sampai sebelah kanan.

9. Supraorbitale kiri-kanan $\left(\mathrm{X}_{9 \mathrm{k}}\right)$ diukur dari penonjolan tulang supraorbitale kiri dan kanan.

\section{Penentuan Genotipe untuk Gen Fekunditas yang} Diamati

Ekstraksi DNA berasal dari sampel darah yang diambil melalui vena jugularis dan ditampung pada tabung vacutainer yang berisi EDTA. Ekstraksi DNA menggunakan metode phenol menurut Sambrook et al. (1989) dengan modifikasi. Sebanyak $100 \mu \mathrm{L}$ sampel darah dipindahkan ke tabung ependorf 1,5 mL dan ditambahkan $1000 \mathrm{uL} \mathrm{NaCl}$ $0,2 \%$, kemudian dikocok selama 5 menit dengan pengocok (vortex) sampai tersuspensi dan segera disentrius pada kecepatan $8000 \mathrm{rpm}$ selama 5 menit. Supernatan dibuang dan ditambahkan proteinase-K sebanyak $10 \mu \mathrm{L}, 350 \mu \mathrm{L}$ 1xSTE (sodium tris-EDTA) serta $40 \mu \mathrm{L} 10 \%$ SDS (sodium dodecylsulfate) dan selanjutnya diinkubasi pada suhu $55^{\circ} \mathrm{C}$ selama 2 jam sambil dikocok perlahan dengan menggunakan alat pemutar (tilting). Tahapan degradasi bahan organik dilakukan dengan cara menambahkan $40 \mu \mathrm{L} \mathrm{NaCl} 5 \mathrm{M}$, $400 \mu \mathrm{L}$ larutan fenol dan $400 \mu \mathrm{L}$ CIAA (chloroform iso amil alcohol) untuk proses degradasi protein. Campuran tersebut dikocok perlahan pada suhu ruang selama 1 jam. Larutan hasil degradasi tersebut disentrifius pada kecepatan 12000 rpm selama 5 menit sehingga terbentuk fase DNA. Bagian bening merupakan DNA dan diambil sebanyak 400 $\mu \mathrm{L}$ dengan menggunakan pipet dan dipindahkan ke dalam tabung baru 1,5 mL. Ke dalamnya ditambahkan $800 \mu \mathrm{L}$ ethanol absolute $(\mathrm{EtOH})$ dan dihomogenkan serta didiamkan semalaman pada suhu $-20^{\circ} \mathrm{C}$. Molekul DNA dipisahkan dari ethanol absolute dengan mensentrifius pada kecepatan 12000 rpm selama 5 menit, kemudiann supernatan dibuang, dan ditambahkan $800 \mu \mathrm{L}$ ethanol $70 \%$ dan disentrifius lagi pada kecepatan $12000 \mathrm{rpm}$ selama 5 menit sehingga terbentuk endapan molekul DNA dengan cara membuang bagian supernatan. Endapan dibiarkan dalam tabung terbuka untuk kemudian didiamkan sampai kering dan disuspensikan dalam $100 \mu \mathrm{L} \mathrm{80 \%} \mathrm{buffer} \mathrm{TE} \mathrm{(tris} \mathrm{EDTA),}$ dikocok sampai homogen dan DNA siap untuk digunakan. Amplifikasi DNA menggunakan metode PCR-RFLP (polymerase chain reaction-restriction fragment length polymorphism) untuk mendeteksi mutasi pada fragmen DNA dengan memanfaatkan situs pemotongan yang khas dari enzim restriksi. Campuran amplifikasi DNA terdiri atas $1 \mu \mathrm{L}$ sampel DNA, 10,85 $\mu \mathrm{L}$ air destilasi, $0,3 \mu \mathrm{L}$ primer, 0,05 $\mu \mathrm{L}$ enzim taq polymerase, $1,5 \mu \mathrm{L}$ buffer, $0,3 \mu \mathrm{L}$ dNTP dan $1 \mu \mathrm{L} \mathrm{MgCl}$ diinkubasi dengan menggunakan mesin PCR thermocycler. Amplifikasi untuk gen BMP15 (exon 1), gen KISS1 (exon 1) dan gen KISS1 (intron 1) melalui beberapa tahapan. Tahap 1 (denaturasi awal) terjadi pada suhu 95 ${ }^{\circ} \mathrm{C}$ selama 5 menit, tahap II (masih denaturasi) pada suhu $95{ }^{\circ} \mathrm{C}$ selama 10 detik, annealing pada suhu $60{ }^{\circ} \mathrm{C}$ selama 20 detik, dan elongasi pada suhu $72^{\circ} \mathrm{C}$ selama 30 detik, dilakukan sebanyak 35 siklus, tahap III post-elongasi) pada suhu $72{ }^{\circ} \mathrm{C}$ selama 5 menit. Amplifikasi untuk gen $B M P R 1 B$ (exon 1) melalui tahap 1 (denaturasi awal) pada suhu 95 
${ }^{\circ} \mathrm{C}$ selama 5 menit, tahap II (masih denaturasi) pada suhu 95 ${ }^{\circ} \mathrm{C}$ selama 10 detik, annealing pada suhu $59{ }^{\circ} \mathrm{C}$ selama 20 detik, dan elongasi pada suhu $72{ }^{\circ} \mathrm{C}$ selama 30 detik yang dilakukan sebanyak 33 siklus, tahap III (post-elongasi) pada suhu $72{ }^{\circ} \mathrm{C}$ selama 5 menit. Tabel 1 menyajikan urutan basa primer dan enzim restriksi yang digunakan.

Hasil amplifikasi DNA (amplikon) divisualisasikan melalui elektroforesis dalam gel agarose 1,5\% (campuran agarose 0,45 g, 0,5 TBE $30 \mathrm{~mL}$ dan 2,5 $\mu \mathrm{L}$ EtBr. Sebanyak $2 \mu \mathrm{L}$ produk PCR dicampur dengan loading dye yang terdiri atas bromthymol blue 0,01\%, xylene cyanol $0,01 \%$ dan gliserol 50\%). Panjang pita DNA yang muncul dibandingkan dengan marker. Elektroforesis menggunakan $2 \mu \mathrm{L}$ amplikon pada tegangan 150 volt selama 60 menit. Setelah elektroforesis, panjang pita DNA pada gel agarose dapat dilihat dengan menggunakan UV-Transilluminator. Sebanyak $2 \mu \mathrm{L}$ produk PCR yang telah dielektroforesis (amplikon) didistribusikan ke dalam tabung 0,5 mL yang ditambahkan $1 \mu \mathrm{L}$ DW (destilated water); 0,3 $\mu \mathrm{L}$ enzim restriksi; $0,7 \mu \mathrm{L}$ buffer $R E$ untuk diinkubasi dalam inkubator pada suhu $37^{\circ} \mathrm{C}$ selama 16 jam. Sampel DNA yang telah dipotong dengan enzim restriksi dielektroforesis pada gel agarose $2 \%$ pada tegangan 100 volt selama 30 menit untuk kemudian dilakukan proses visualisasi dengan UV-Transilluminator. Panjang pita DNA yang muncul dibandingkan dengan DNA marker 100 pb. Satu posisi migrasi yang sama dianggap sebagai satu tipe atau satu alel DNA. Setiap pita DNA dari setiap sampel dibandingkan untuk menentukan genotipe pita DNA.

Pengukuran Konsentrasi Progesteron Serum Darah dan Kebuntingan sampai dengan Beranak

Darah diambil sebanyak enam kali, yaitu pada minggu ke -5, 6, 7, 8, 11 dan 13 setelah kambing betina calon induk kawin. Syringe berukuran $5 \mathrm{~mL}$ digunakan untuk mengambil darah kambing betina calon induk melalui vena jugularis dan darah ditampung pada tabung vacutainer plain untuk diambil serumnya, setelah disentrifius pada kecepatan 1500 rpm selama 10 menit. Serum kemudian ditempatkan pada freezer pada suhu $-20{ }^{\circ} \mathrm{C}$ sebelum diamati konsentrasi progesteronnya. Alat bantu untuk diagnosis kebuntingan EIA (enzyme immuno assay) digunakan untuk mengukur konsentrasi progesteron serum darah, yang dilakukan oleh jasa layanan Laboratorium Hormon, Divisi Reproduksi dan Rehabilitasi, Departemen Klinik, Reproduksi dan Patologi, Fakultas Kedokteran Hewan IPB. Konsentrasi progesteron serum darah dilakukan pada minggu ke-5 setelah kambing betina calon induk dikawinkan, yang kemudian diulang kembali pada minggu ke-6, 7, 8, 11 dan 13. Diagnosis kebuntingan diverifikasi pada saat kambing tersebut beranak.

\section{Prosedur Analisis Data}

\section{Analisis Data Pengukuran Tubuh dan Kepala}

Data ukuran permukaan tubuh dan kepala linear diolah secara deskriptif (Walpole 1993) dan AKU (analisis komponen utama) menurut Gaspersz (1992). Persamaan ukuran dan bentuk tubuh diperoleh berdasarkan AKU. Model matematika AKU dengan persamaan ukuran dan bentuk tubuh dan kepala diturunkan dari matriks kovarian berdasarkan Gaspersz (1992) dengan rumus berikut ini.

$$
\begin{aligned}
& Y_{1 t}=a_{11} X_{1 t}+a_{21} X_{2 t}+\cdots+a_{91} X_{9 t} \\
& Y_{2 t}=a_{12} X_{1 t}+a_{22} X_{2 t}+\cdots+a_{92} X_{9 t} \\
& \mathrm{Y}_{1 \mathrm{t}} \quad=\text { skor ukuran tubuh } \\
& \mathrm{Y}_{2 \mathrm{t}}^{\mathrm{lt}} \quad=\text { skor bentuk tubuh } \\
& \mathrm{a}_{11}-\mathrm{a}_{91}=\text { vektor eigen untuk persamaan ukuran tubuh } \\
& \mathrm{a}_{12}-\mathrm{a}_{92}=\text { vektor eigen untuk persamaan bentuk tubuh } \\
& \mathrm{X}_{1 \mathrm{t}} \quad=\text { tinggi pundak } \\
& \mathrm{X}_{2 \mathrm{t}} \quad=\text { tinggi pinggul } \\
& \mathrm{X}_{3 \mathrm{t}} \quad=\text { panjang badan } \\
& \mathrm{X}_{4 \mathrm{t}}^{3 \mathrm{t}} \quad=\text { lebar dada } \\
& \mathrm{X}_{5 \mathrm{t}} \quad=\text { dalam dada } \\
& \mathrm{X}_{6 \mathrm{t}} \quad=\text { lebar pinggul } \\
& \mathrm{X}_{7 \mathrm{t}} \quad=\text { panjang kelangkang } \\
& \mathrm{X}_{8 \mathrm{t}} \quad=\text { lingkar dada } \\
& \mathrm{X}_{9 \mathrm{t}} \quad=\text { lingkar kanon } \\
& Y_{1 k}=a_{11} X_{1 k}+a_{21} X_{2 k}+\cdots+a_{91} X_{9 k} \\
& Y_{2 k}=a_{12} X_{1 k}+a_{22} X_{2 k}+\cdots+a_{92} X_{9 k} \\
& \mathrm{Y}_{1 \mathrm{k}} \quad=\text { skor ukuran kepala } \\
& \mathrm{Y}_{2 \mathrm{k}} \quad=\text { skor bentuk kepala } \\
& \mathrm{a}_{11}-\mathrm{a}_{91}=\text { vektor eigen untuk persamaan ukuran kepala } \\
& \mathrm{a}_{12}-\mathrm{a}_{92}=\text { vektor eigen untuk persamaan bentuk kepala } \\
& \mathrm{X}_{1 \mathrm{k}} \quad=\text { akrokranion-prosthion } \\
& \mathrm{X}_{2 \mathrm{k}} \quad=\text { basion-prosthion } \\
& \mathrm{X}_{3 \mathrm{k}} \quad=\text { panjang rahang bawah } \\
& \mathrm{X}_{4 \mathrm{k}} \quad=\text { tinggi kepala } \\
& \mathrm{X}_{5 \mathrm{k}} \quad=\text { tuber facial kiri-kanan } \\
& \mathrm{X}_{6 \mathrm{k}} \quad=\text { nasion-rhinion } \\
& \mathrm{X}_{7 \mathrm{k}} \quad=\text { entorbitale kiri-kanan } \\
& \mathrm{X}_{8 \mathrm{k}} \quad=\text { euryon kiri-kanan } \\
& \mathrm{X}_{9 \mathrm{k}} \quad=\text { supraorbitale } \text { kiri-kanan }
\end{aligned}
$$

\section{Analisis Deskriptif Variabel-variabel yang Diamati}

Data USG, status kebuntingan sampai dengan beranak, konsentrasi progesteron pada minggu ke -5, 6, 7, 8, 11 dan 13 setelah kawin, skor ukuran tubuh dan kepala, skor bentuk tubuh dan kepala, genotipe dari gen fekunditas yang meliputi gen $B M P 15$ (exon 1), gen BMPR1B (exon 1), gen KISS1 (exon 1) dan gen KISS 1 (intron 1) setiap individu kambing PE betina calon induk; diamati dan dibandingkan satu sama lain yang secara deskriptif dihubungkan dengan profil hormon progesteron terhadap litter size.

\section{HASIL DAN PEMBAHASAN}

Ukuran permukaan tubuh dan kepala linear dari enam ekor kambing PE betina calon induk disajikan pada Tabel 2 dan 3, sedangkan skor ukuran tubuh dan skor bentuk tubuh, serta skor ukuran kepala dan skor bentuk kepala pada Tabel 4. Skor bentuk tubuh dan kepala pada kambing PE betina calon induk tidak dibahas dalam karena sifat bentuk lebih bersifat genetik dibadingkan dengan sifat ukuran tubuh dan kepala (Everitt dan Dunn 1998). Genotipe dari gen fekunditas yang diamati disajikan pada Tabel 5. Konsentrasi progesteron pada minggu ke $-5,6,7,8,11$ dan 13 setelah kawin disajikan pada Tabel 6. Konsumsi bahan kering, protein kasar dan lemak kasar pada kambing PE betina 
Mulyono et al.

Jurnal Ilmu Produksi dan Teknologi Hasil Peternakan 6 (1): 19-26

Tabel 1. Urutan primer gen fekunditas dan enzim restriksi yang digunakan

\begin{tabular}{lllc}
\hline Primer dan tempat gen & Urutan primer $\left(5^{\prime}-3^{\prime}\right)$ & Amplikon & Suhu annealing $\left({ }^{\circ} \mathrm{C}\right)$ \\
\hline BMP15 (exon 1)a, b & F: GTGGAGCCTGGATGCTGTTA & $279 \mathrm{pb}(24-302)$ & 60 \\
& R: CGGCTTCCTCTGCTGCTTG & \\
& Enzim restriksi: AluI & $784 \mathrm{pb}(377-1160)$ & 59 \\
BMPR1B (exon 1)b & F: TGTCTACCATCGTTTCTTCCACT & \\
& R: GGACAATGGTGGTGGCATTTAC & \\
& Enzim restriksi: SduI & $594 \mathrm{pb}(424-1007)$ \\
KISS1 (exon 1)c & F: TGCAAAGCCGAGTGTGCAGG & \\
& R: TGAAGGCGGTGGCACAAAGGAA & \\
KISS1 (intron 1)c & Enzim restriksi: BsrI & $377 \mathrm{pb}(2000-2376)$ \\
& F: CCCGCTGTAACTAGAGAAAG & \\
& R: CATCCAGGGTGAGTGATACT & \\
& Enzim restriksi: MwoI & \\
\hline
\end{tabular}

aSumber: Chu et al. (2007) untuk primer R, bdidisain sendiri, csumber: An et al. (2013).

Tabel 2. Rataan ukuran-ukuran permukaan tubuh linear kambing PE betina calon induk yang diamati

\begin{tabular}{lc}
\hline Variabel & $\begin{array}{c}\text { Ukuran permukaan tubuh } \\
\text { linear }(\mathrm{cm}) \\
(\mathrm{na}=6)\end{array}$ \\
\hline Tinggi pundak (X1t) & $62,27 \pm 2,87(4,27 \%)$ \\
Tinggi pinggul(X2t) & $70,73 \pm 3,98(72 \%)$ \\
Panjang badan (X3t) & $63,92 \pm 4,99(7,81 \%)$ \\
Lebar dada (X4t) & $13,95 \pm 1,92(13,78 \%)$ \\
Dalam dada (X5t) & $26,80 \pm 1,91(7,11 \%)$ \\
Lebar pinggul (X6t) & $14,95 \pm 0,93(6,21 \%)$ \\
Panjang kelangkang (X7t) & $11,10 \pm 1,50(13,52 \%)$ \\
Lingkar dada (X8t) & $67,17 \pm 25(7,67 \%)$ \\
Lingkar kanon (X9t) & $11,75 \pm 0,88(7,49 \%)$ \\
\hline
\end{tabular}

a Jumlah ternak (ekor); b persen dalam tanda kurung menunjukkan koefisien keragaman,

Tabel 3. Rataan ukuran-ukuran permukaan kepala linear kambing PE betina calon induk yang diamati

\begin{tabular}{lc}
\hline \multicolumn{1}{c}{ Variabel } & $\begin{array}{c}\text { Ukuran permukaan kepala } \\
\text { linear }(\mathrm{cm}) \\
(\mathrm{na}=6)\end{array}$ \\
\hline Akrokranion-Prosthion (X1k) & $\begin{array}{c}18,67 \pm 0,95(20 \%) \mathrm{b} \\
22,63 \pm 1,60(7,06 \%)\end{array}$ \\
Basion-Prosthion (X2k) & $13,47 \pm 2,10(170 \%)$ \\
Panjang rahang bawah (X3k) & $15,00 \pm 1,29(8,59 \%)$ \\
Tinggi kepala (X4k) & $4,12 \pm 0,76(18,46 \%)$ \\
Tuber facial kiri-kanan (X5k) & $10,28 \pm 1,62(15,71 \%)$ \\
Nasion-Rhinion (X6k) & $3,73 \pm 0,68(18,19 \%)$ \\
Entorbitale kiri-kanan (X7k) & $7,54 \pm 0,68(8,99 \%)$ \\
Euryon kiri-kanan (X8k) & $5,81 \pm 1,32(22,63 \%)$ \\
Supraorbitale kiri-kanan (X9k)
\end{tabular}

a Jumlah ternak (ekor); bpersen dalam tanda kurung menunjukkan koefisien keragaman, calon induk disajikan pada Tabel 7. Deteksi kebuntingan dini pada kambing PE betina calon induk menggunakan ultrasonography (USG) dimensi dua untuk reproduksi. Menurut Santoso et al. (2016) warna hitam pada layar (anechoic) terjadi sebagai akibat cairan awal konsepsi yang terbentuk sehingga diasumsikan kebuntingan telah terjadi.

Hasil penelitian menunjukkan bahwa kambing PE betina calon induk nomor 1 tidak menghasilkan anak, berdasarkan Tabel 4, 5, 6 dan 7, tetapi USG memperlihatkan warna hitam pada layar (anechoic) yang menunjukkan kebuntingan. Skor ukuran kambing PE betina induk nomor 1 sedang, bahkan memiliki skor ukuran kepala yang terbesar (Tabel 4). Kambing PE betina calon induk nomor 1 mengkonsumsi bahan kering, protein kasar dan lemak kasar paling rendah dan kurang dari kebutuhan untuk kambing bunting pada rasio protein : energi atau $\left(\mathrm{P} / \mathrm{E}_{\text {lemak }}\right)$ yang tidak seimbang yaitu sebesar 4,148. Menurut NRC (1981) kebutuhan nutrisi harian yang berasal dari bahan pakan pada kambing berbobot sekitar 20-30 kg yang sedang mengalami kebuntingan awal pada kondisi lingkungan tropik adalah sebanyak 334-452 g TDN (energi pakan yang disetarakan dengan energi dari karbohidrat) dan 46-62 g protein (NRC 1981) dengan rasio protein : energi atau $(\mathrm{P} / \mathrm{E})$ sebesar 0,137-0,138. Pada penelitian ini, pemberian protein kasar pakan memenuhi syarat, sedangkan pemberian energi pakan pada kambing betina calon induk hanya berasal dari lemak kasar yang memperlihatkan kebuntingan pada taraf di atas $45 \mathrm{~g}$ atau pada rasio protein : energi atau $\left(\mathrm{P} / \mathrm{E}_{\text {lemak }}\right)$ sebesar 2,184.

Perbandingan antara kambing PE betina calon induk nomor 1 dan 3 memperlihatkan genotipe yang sama untuk gen BMP15 (exon 1), BMPR1B (exon 1), KISS1 (exon 1) dan KISS1 (intron 1), berturut-turut adalah GG, GG, GG dan TT, namun betina nomor 1 tidak bunting dan betina nomor 3 mengalami keguguran (Tabel 4 dan 5). Konsentrasi progesteron serum darah pada kedua betina calon induk tersebut bertahan sampai dengan minggu ke-13 setelah kawin, dengan kesamaan profil konsentrasi progesteron pada minggu ke -5, 6, 7, 8, 11 dan 13 setelah kawin (Tabel 6). Berdasarkan penelitian sebelumnya, kebuntingan 
Mulyono et al.

Jurnal Ilmu Produksi dan Teknologi Hasil Peternakan 6 (1): 19-26

Tabel 4. Skor ukuran, skor bentuk tubuh dan kepala serta hasil akhir setelah kawin pada betina calon induk

\begin{tabular}{llllll}
\hline Betina calon induk & Tubuh & \multicolumn{5}{l}{ Kepala } \\
& Ukuran (size) & Bentuk (shape) & Ukuran (size) & Bentuk (shape) & Hasil akhir \\
\hline No.1 & 132,467 & 3,302 & 28,264 & 25,409 & Kosong \\
No.2 & 124,680 & 9,556 & 19,561 & 26,017 & Kosong \\
No.3 & 143,051 & 11,506 & 23,566 & 29,345 & Keguguran \\
No.4 & 125,003 & 16,028 & 23,392 & 24,043 & Kosong \\
No.5 & 138,500 & 15,544 & 26,660 & 27,194 & 1 anak + \\
No.6 & 129,711 & 13,655 & 24,098 & 24,764 & 1 anak 0 \\
\hline
\end{tabular}

Tabel 5. Genotipe dari gen fekunditas dan hasil akhir setelah kawin pada betina calon induk

\begin{tabular}{lccccl}
\hline $\begin{array}{l}\text { Betina } \\
\text { calon } \\
\text { induk }\end{array}$ & $\begin{array}{l}\text { BMP15 } \\
\text { (exon 1) }\end{array}$ & $\begin{array}{l}\text { BMPR1B } \\
\text { (exon 1) }\end{array}$ & $\begin{array}{l}\text { KISS1 } \\
\text { (exon 1) }\end{array}$ & $\begin{array}{l}\text { KISS1 } \\
\text { (intron1) }\end{array}$ & Hasil akhir \\
\hline No.1 & GG & GG & GG & TT & Kosong \\
No.2 & GG & CC & GG & AT & Kosong \\
No.3 & GG & GG & GG & TT & Keguguran \\
No.4 & GG & CC & GG & TT & Kosong \\
No.5 & GG & CC & GG & TT & 1 anak + \\
No.6 & GG & CC & GG & TT & 1 anak $\precsim$ \\
\hline
\end{tabular}

dapat terjadi pada level progesteron yaitu di atas 2,5-3,5 $\mathrm{ng} \mathrm{mL}^{-1}$ (Thornburn dan Schneider 1972), di atas $3 \mathrm{ng}$ $\mathrm{mL}^{-1}$ (Sardjana 1994) dan lebih besar dari 1,5 dan 2,5 ng $\mathrm{mL}^{-1}$ (Boscos et al. 2003). Kondisi yang memungkinkan kebuntingan pada kambing PE betina calon induk nomor 1. Menurut Sardjana (1994) kambing yang tidak beranak walau memiliki konsentrasi progesteron yang lebih besar dari $3 \mathrm{ng} \mathrm{mL} \mathrm{m}^{-1}$ terjadi karena resorpsi embrio atau karena keguguran yang tidak diketahui atau karena faktor penyakit yang mengganggu kebuntingan. Dijelaskan lebih lanjut bahwa kematian awal embrio pada kambing sampai dengan kebuntingan hari ke-90 disebabkan gangguan pertumbuhan plasenta, pengurangan jumlah anak yang seharusnya lahir, kondisi tubuh anak yang buruk, embrio yang lemah, dan kondisi kambing betina induk yang buruk.

Kambing PE betina nomor 2 pada penelitian ini beranak (Tabel 4, 5, 6 dan 7), dengan hasil USG yang memperlihatkan kekosongan. Skor ukuran tubuh dan kepala betina calon induk nomor 2 kecil (Tabel 4). Betina calon induk ini sama dengan betina calon induk nomor 1 dan 4 mengkonsumsi lemak kasar yang rendah yang berakibat pada kegagalan beranak dengan rasio protein : energi atau $\left(\mathrm{P} / \mathrm{E}_{\text {lemak }}\right)$ yang tidak seimbang, yaitu sebesar 4,148 . Khotijah (2014) melaporkan bahwa pemberian pakan dengan tambahan asam lemak tidak jenuh berantai panjang yaitu linoleat (berasal dari minyak biji bunga matahari Helianthus annuus Linn.) dapat meningkatkan kejadian anak kembar pada domba prolifik. Asam lemak tak jenuh yang dikandung lemak kasar yang dikonsumsi tidak cukup untuk menambah energi pada ketiga kambing betina calon induk tersebut yang diperlukan untuk proses pematangan sel telur dan ovulasi. Kondisi ukuran tubuh dan kepala betina calon induk nomor 2 ini juga tergolong kecil. Genotipe kambing PE betina induk nomor 2 untuk gen $B M P 15$ (exon 1), BMPR1B (exon 1), KISS1 (exon 1) dan KISS1 (intron 1) berbeda sendiri dibandingkan dengan betina lain, yaitu GG, CC, GG dan AT berturut-turut, yang memiliki profil konsentrasi progesteron serum darah yang rendah pada pengamatan minggu ke -5, 6, 7, 8, 11 dan 13 setelah kawin, sehingga tidak menghasilkan anak. Konsentrasi progesteron pada betina ini di bawah dari yang dilaporkan untuk bunting menurut Thornburn dan Schneider (1972), Sardjana (1994) dan Boscos et al. (2003).

Pengamatan USG tidak selalu memberikan hasil yang bersesuaian dengan kebuntingan. Hasil USG pada betina calon induk nomor 3 memperlihatkan kekosongan, tetapi betina calon induk ini bunting dan mengalami keguguran (Tabel 4, 5, 6 dan 7). Skor ukuran tubuhnya besar, dengan skor ukuran kepala kecil (Tabel 4). Konsumsi lemak kasar pada kambing betina calon induk nomor 3 lebih rendah dibandingkan dengan betina induk nomor 5 dan 6 dengan rasio protein : energi atau $\left(\mathrm{P} / \mathrm{E}_{\text {lemak }}\right)$ yang tidak seimbang yaitu sebesar 3,980. hal ini menunjukkan bahwa lemak kasar yang mengandung asam lemak tidak jenuh yang merupakan tambahan energi pada kambing betina induk nomor 3, belum cukup untuk mempertahankan kebuntingan sampai dengan melahirkan. Profil konsentrasi progesteron betina induk nomor 3 ditemukan tinggi pada pengamatan minggu ke -5, 6, 7, 8, 11 dan 13 setelah kawin, dan terbukti dapat mempertahankan keberadaan janin, tetapi kemudian mengalami keguguran (Tabel 6). Hal ini yang terjadi pada genotipe untuk gen BMP15 (exon 1), BMPR1B (exon 1), KISS1 (exon 1) dan KISS1 (intron 1), berturut-turut yaitu GG, GG, GG dan TT.

Hasil USG yang diduga kosong pada kambing PE betina calon induk nomor 4, bersesuaian dengan hasil akhir bahwa kambing PE betina induk nomor 4 tidak beranak (Tabel 4, 5, 6 dan 7) dengan skor ukuran tubuh dan kepala yang kecil. Konsumsi lemak kasar pada betina induk ini, di bawah dari betina induk lain yang berhasil bunting (betina calon induk nomor 3, 5 dan 6). Rasio protein : energi atau $\left(\mathrm{P} / \mathrm{E}_{\text {lemak }}\right)$ tidak seimbang, yaitu 3,980. Betina calon induk nomor 4 ini meskipun memiliki genotipe yang sama dengan betina colon induk nomr 5 dan 6 yaitu berturut-turut untuk gen BMP15 (exon 1), BMPR1B (exon 1), KISS1 (exon 1) dan KISS1 (intron 1), adalah GG, CC, GG dan TT (Tabel 5), tetapi tidak memiliki anak, menunjukkan bahwa genotipe tidak berhubungan dengan sifat memiliki anak karena perbedaan profil progesteron yang semakin rendah dari 
Mulyono et al.

Jurnal Ilmu Produksi dan Teknologi Hasil Peternakan 6 (1): 19-26

Tabel 6, Konsentrasi progesteron serum darah kambing PE betina calon induk (ng mL-1) pada minggu ke -5, 6, 7, 8, 11 dan 13 setelah kawin serta hasil akhir

\begin{tabular}{llllllll}
\hline Betina calon induk & \multicolumn{9}{l}{ Pengambilan darah minggu ke- setelah kawin } & \multicolumn{3}{l}{ Hasil } \\
\cline { 2 - 8 } & 5 & 6 & 7 & 8 & 11 & 13 & Kosong \\
\hline No.1 & 10,8 & 7,2 & $-\mathrm{a}$ & - & 22 & 14 & Kosong \\
No.2 & 0,4 & 0,4 & 0,4 & 0,4 & 8,4 & 0,8 & Keguguran \\
No.3 & 13,2 & 8,4 & 8,4 & 12 & 3,6 & 25,6 & Kosong \\
No.4 & 9,6 & 6 & 2 & 2,4 & 0,8 & 0,8 & 1 anak + \\
No.5 & 13,2 & 11,2 & - & - & 12 & 17,2 & 1 anak ${ }^{\lambda}$ \\
No.6 & 16,8 & 14 & 14 & 13,6 & - & - & \\
\hline
\end{tabular}

a - =tidak terdeteksi,

Tabel 7. Bahan kering, protein kasar dan lemak kasar yang diberikan pada kambing PE betina calaon induk (g ekor-1 hari-1)

\begin{tabular}{llllc}
\hline $\begin{array}{l}\text { Betina calon } \\
\text { induk }\end{array}$ & $\begin{array}{l}\text { Bahan } \\
\text { keringa }\end{array}$ & $\begin{array}{l}\text { Protein } \\
\text { kasara }\end{array}$ & $\begin{array}{l}\text { Lemak } \\
\text { kasara }\end{array}$ & Hasil akhir \\
\hline 1 & 683,34 & 94,28 & 22,73 & $-\mathrm{b}$ \\
2 & 920,62 & 127,02 & 30,62 & - \\
3 & 986,52 & 139,29 & 35 & Keguguran \\
4 & 850,16 & 120,03 & 30,16 & - \\
5 & 734,56 & 104,05 & 47,64 & 1 anak $\varnothing$ \\
6 & 716,24 & 101,45 & 46,45 & 1 anak $\hat{~}$ \\
\hline
\end{tabular}

aSumber: Laboratorium Analisis Nutrisi Ternak Daging dan Kerja, Departemen Ilmu Nutrisi dan Teknologi Pakan, Fakultas Peternakan IPB, b kosong,

pengamatan minggu ke -5, 6, 7, 8, 11 dan 13 setelah kawin (Tabel 6). Konsentrasi progesteron selama kehamilan awal sampai dengan minggu ke-6 setelah dikawinkan masih di atas 2.5-3.5 $\mathrm{ng} \mathrm{mL}^{-1}$.

Kambing PE betina calon induk nomor 5 dan 6 memiliki satu ekor anak betina (Tabel 4, 5, 6 dan 7) dan tidak bertentangan dengan hasil USG. Skor ukuran tubuh dan kepala kambing PE betina calon induk nomor 5 sedang, sedangkan betina calon induk nomor 6 nerukuran kecil (Tabel 4). Perbedaan ukuran tubuh dan kepala pada kedua betina calon induk ini tidak mempengaruhi proses kebuntingan dan memiliki anak. Hal ini diduga karena konsumsi lemak kasar pada kedua betina calon induk tersebut yang memungkinkan untuk memiliki anak, yaitu pada 47,64 dan 46,45 $\mathrm{g}_{\text {ekor }}{ }^{-1}$ hari $^{-1}$, pada rasio protein : energi atau ( $\left.\mathrm{P} / \mathrm{E}_{\text {lemak }}\right)$ seimbang, yaitu sebesar 2,184 (Tabel 7). Genotipe betina calon induk nomor 5 dan 6 untuk gen BMP15 (exon 1), BMPR1B (exon 1), KISS1 (exon 1) dan KISS1 (intron 1) yaitu GG, CC, GG dan TT (Tabel 5). Profil konsentrasi progesteron pada pengamatan minggu ke $-5,6$, 7, 8, 11 dan 13 setelah kawin juga ditemukan tinggi pada betina calon induk nomor 5 dan 6 ini (Tabel 6).

Keterbatasan jumlah betina calon induk yang bunting menyebabkan hubungan antara level progesteron selama periode kebuntingan dengan litter size sulit ditentukan, tetapi betina calon induk dengan profil progesteron yang tinggi dan bertahan sampai dengan pengamatan minggu ke-13 setelah kawin, memiliki kecenderungan memiliki anak, yang didukung dengan konsumsi lemak kasar yang tinggi pula. Disamping itu keterbatasan jumlah betina yang bunting dalam penelitian ini menyebabkan hubungan antara level progesteron selama periode kebuntingan dengan litter size sulit ditentukan. Profil progesteron berkaitan dengan keberhasilan betina induk mempunyai anak. Induk yang memiliki konsentrasi progesteron yang tinggi dan bertahan sampai dengan pengamatan minggu ke-13 setelah kawin, memiliki kecenderungan memiliki anak, yang didukung dengan konsumsi lemak kasar yang tinggi pula. Keterkaitan sifat kembar pada gen fekunditas yang diamati pada penelitian ini belum dapat dibuktikan karena disamping keterbatasan jumlah betina calon induk, juga karena pada penelitian ini tidak ditemukan kejadian kembar. Hasil pengamatan ini menunjukkan bahwa ukuran tubuh dan kepala tidak terkait dengan profil progesteron pada pengamatan minggu ke- 5, 6, 7, 8, 11 dan 13 setelah kawin. Kambing betina calon induk yang beranak pada genotipe GG, CC, GG dan TT, masing-masing untuk gen fekunditas BMP15 (exon 1), BMPR1B (exon 1), KISS1 (exon 1) dan KISS1 (intron 1), yang juga didukung dengan konsumsi lemak kasar yang lebih tinggi.

\section{KESIMPULAN}

Keterkaitan antara konsumsi lemak kasar dan profil progesteron ditemukan pada penelitian ini, tetapi keterkaitannya dengan kelahiran kembar dengan genotipe tertentu dari gen fekunditas BMP15 (exon 1), BMPR1B (exon 1), KISS1 (exon 1) dan KISS1 (intron 1) tidak ditemukan. Profil progesteron selama periode kebuntingan tidak berkorelasi dengan ukuran tubuh dan kepala tetapi konsumsi lemak kasar mempengaruhinya.

\section{DAFTAR PUSTAKA}

Amano T, Katsumata M, Suzuki S. 1981. Morphological and genetical survey of water buffaloes in Indonesia. The Origin and Phylogeny of Indones Native Livestock. Part II: 31-54.

An X, Ma T, Hou J, Fang F, Han P, Yan Y, Zhao H, Song Y, Wang J, Cao B. 2013. Association analysis between variants in KISS1 gene and litter size in goats. BMC Genetics. 14 (63):1-6. http://www. biomedcentral. com/ 1471-2156/14/63.

Atabany A, Abdulgani IK, Sudono A, Mudikdjo. 2001. 
Performa produksi, reproduksi dan nilai ekonomis kambing Peranakan Etawah di peternakan Barokah. Med. Pet 24 (2): 1-7.

Batubara A, Nasution S, Subandryo, Inounu I, Tiesnamurti B, Anggraini A. 2016. Kambing Peranakan Etawah (PE). Jakarta (ID): IAARD Press.

Boscos CM, Samartzi FC, Lymberopoulos AG, Stefanakis A, Belibasaki S. 2003. Assessment of progesterone concentration using enzymeimmunoassay, for early pregnancy diagnosis in sheep and goats. Reprod. Dom. Anim. 38: 170-174.

Chu MX, Jiao CL, He YQ, Wang JY, Liu ZH, Chen GH. 2007. Association between PCR-SSCP of bone morphogenetic protein 15 gene and prolificacy in jining grey goats. Anim Biotech. 18: 263-274.doi: 10.1080/ 10495390701331114.

Everitt BS, Dunn G.1998. Applied Multivariate Data Analysis. New York (US): Halsted Press.

Gaspersz V. 1992. Teknik Analisis dalam Penelitian Percobaan. Jilid 1. Bandung (ID): Tarsito.

Hayashi Y, Nishida T, Otsuka J, Abdulgani IK. 1980. Measurement of the skull of native cattle and banteng in Indonesia. The Origin and Phylogeny of Indonesian Native Livestock. Part I: 19-27.

Khotijah L. 2014. Performa reproduksi dan ketahanan tubuh anak domba prolifik berbasis pakan lokal dengan sumber linoleat minyak bunga matahari (Helianthus annuus Linn.) [disertasi].Bogor (ID): Institut Pertanian Bogor.

Kostaman T, Sutama IK. 2006. Korelasi bobot badan induk dengan lama bunting, litter size dan bobot lahir anak. Seminar Nasional Teknologi Peternakan dan Veteriner Balai Penelitian Ternak. Bogor (ID) : Balai Penelitian Ternak.

[NRC] National Research Council. 1981. Nutrient Requiremnents of Goats: Angora, Dairy and Meat Goats in Temperate and Tropical Countries. Washington DC (US): National Academy Press.
Rout PK, Dass G. 2015. Factors affecting body weights and milk production traits in jamnapari goats. Bhartiya Krishi Anushandhan Patrika 30(1): 46-49.

Sambrook J, Fritsch EF, Medrano JF. 1989. Molecular Cloning: A Laboratory Manual. Ed ke-2. New York (US): Cold Spring Harbor Laboratory Pr.

Santoso, Amrozi, B Purwantara, Herdis. 2016. Sonogram of early pregnancy diagnosis in Kacang goat (Capra hircus). JSV 34(2): 188-193.

Sardjana IKW. 1994. Diagnosa kebuntingan dini melalui pengukuran hormon progesterone pada air susu kambing untuk meningkatkan produksi ternak. Bul FKH-UGM XIII: 17-22.

Sutama IK. 2009. Productive and reproductive performances of female etawah crossbred goats in Indonesia. Wartazoa Indones Bull of Anim and Vet Sci.19 (1): 1-6.

Sutama IK, Budiarsana IGM, Supriyati, Hastono. 2012. Perlakuan Progesteron eksogenus selama bunting untuk meningkatkan produksi susu dan pertumbuhan anak pada kambing Peranakan Etawah. JITV 17(2): 83-91.

Temple RS. 1993. Reproduksi dan persilangan. Di dalam: Williamson G, Payne WJA, editor. Pengantar Peternakan di Daerah Tropis. Darmadja SGND, penerjemah; Djagra IB, editor. Yogyakarta (ID): Gadjah Mada University Press. Terjemahan dari: An Introduction to Animal Husbandry in the Tropics.

Thornburn GD, Schneider W. 1972. The progesterone concentration in the plas-ma of the goat during the oestrous cycle and pregnancy. J Endocr. 52: 23-36.

Walpole R. 1993. Pengantar Statistika. Sumantri B, penerjemah. Jakarta (ID): Gramedia. Terjemahan dari: Introduction to Statistics. 